\title{
EFFECTS OF WINEMAKING ON 'MARSELAN’ RED WINES: VOLATILE COMPOUNDS AND SENSORY ASPECTS
}

\section{EFEITOS DE DIFERENTES PROCESSOS DE VINIFICAÇÃO EM VINHOS TINTOS ‘MARSELAN': COMPOSTOS VOLÁTEIS E ASPECTOS SENSORIAIS}

\author{
Marianna Pozzatti $^{1 *}$, Celito C. Guerra ${ }^{2}$, Guilherme Martins ${ }^{3,4}$, Ingrid D. dos Santos ${ }^{5}$, Roger Wagner ${ }^{5}$, Marco \\ F. Ferrão ${ }^{6}$, Vitor Manfroi ${ }^{1}$
}

${ }^{1}$ Instituto de Ciência e Tecnologia de Alimentos, Universidade Federal do Rio Grande do Sul, Av. Bento Gonçalves, 9500, Prédio 43.212, Campus do Vale, CEP 91501-970, Porto Alegre, RS, Brazil.

${ }^{2}$ LACEM-Laboratório de Cromatografia e Espectrometria de Massas, Embrapa Uva e Vinho, Rua Livramento, 515, Bento Gonçalves, RS 95700000, Brazil.

${ }^{3}$ Université de Bordeaux, ISVV, Unité de recherche Enologie EA 4577, USC 1366 INRA, Bordeaux INP, 33140 Villenave d'Ornon, France.

${ }^{4}$ Bordeaux Sciences Agro, 33170 Gradignan Cedex, France.

${ }^{5}$ Programa de Pós-graduação em Ciência e Tecnologia de Alimentos, Universidade Federal de Santa Maria, Av. Roraima, 1000, Prédio 42, Sala 3210, CEP 97105-900 Santa Maria, RS, Brazil.

${ }^{6}$ Instituto de Química, Universidade Federal do Rio Grande do Sul, Av. Bento Gonçalves, 9500, Prédio 43.121, Campus do Vale, Bairro Agronomia, CEP 91501-970, Porto Alegre, RS, Brazil.

* Corresponding author: Tel.: +55-54-984397102, e-mail: mariannapms@hotmail.com

\section{SUMMARY}

Winemaking processes and volatile compounds perform an important role in contributing to the quality of wines. 'Marselan' is a red grape variety grown in several countries such as France, Brazil and China. This variety has gained international interest in recent years. The volatile profile of Brazilian 'Marselan' red wines during various winemaking processes was studied. Four processes were applied: thermovinification, integrale vinification, classic winemaking and classic winemaking pretreated with ultrasound. The wines were characterized with conventional physicochemical analyses, volatile composition and sensory analysis. Sixty-three volatile compounds were identified and semi-quantified. The wines presented different sensory characteristics. The thermovinification and classic winemaking with ultrasound application methods showed a large presence of esters contributing to a fruity and overmaturation aroma in the volatile profile and sensory analysis. An increased presence of vegetal and sulfurous aromas was observed in the wines from the classic winemaking and integrale vinification processes. This effect was most likely attributed to the lower influence of esters which generated a greater perception of other compounds and conferred these aromas. The differences can be directly linked to the various extraction rates in the vinification processes, which result in different interactions between the compounds.

\section{RESUMO}

Os processos de vinificação e a composição volátil são fatores muito importantes para a qualidade dos vinhos. 'Marselan' é uma casta tinta cultivada em diversos países, como França, Brasil e China. Além disso, esta variedade vem ganhando maior interesse internacional nos últimos anos. Neste trabalho, foi estudado o perfil volátil de vinhos oriundos da uva 'Marselan', submetidos a diferentes processos de vinificação. Foram aplicados quatro processos: termovinificação, vinificação integral, vinificação clássica e vinificação clássica com aplicação de ultrassom. Os vinhos foram caracterizados por análises físico-químicas, composição volátil e análise sensorial. Sessenta e três compostos voláteis foram identificados e semi-quantificados. Os vinhos apresentaram diferentes características sensoriais. A composição volátil mostrou uma grande presença de ésteres, que contribuiram para um aroma frutado e de sobrematuração nos processos de termovinificação e vinificação clássica com aplicação de ultrassom. A presença de aromas vegetais e sulfurosos foi observada nos processos de vinificação clássica e vinificação integral. Este efeito provavelmente ocorreu devido à menor influência de ésteres, gerando maior percepção de outros compostos que conferem estes aromas. As diferenças podem estar diretamente ligadas às diferentes taxas de extração nos processos de vinificação, que subsequentemente resultam em diferentes interações entre os compostos.

Key words: Volatile profile, thermovinification, integrale vinification, ultrasound application, Marselan wine quality.

Palavras-chave: Perfil volátil, termovinificação, vinificação integral, aplicação de ultrassom, qualidade do vinho Marselan.

\section{3}

This is an Open Access article distributed under the terms of the Creative Commons Attribution License (http://creativecommons.org/licenses/by/4.0), which permits unrestricted use, distribution, and reproduction in any medium, provided the original work is properly cited. 


\section{INTRODUCTION}

Wine is a complex alcoholic beverage formed by several compounds. Aroma compounds are one of the most important groups to determine the level of quality in a wine (Villamor and Ross, 2013; Fariña et al., 2015). The grape variety and the technology used during winemaking are crucial for odor quality in wines (Geffroy et al., 2015; Ostapenko et al., 2017; De Castilhos et al., 2019). 'Marselan' is a red grape variety that resulted of the crossing of 'Cabernet Sauvignon' and 'Grenache' grapevine varieties in Marseille, France. The wine presents a high degree of phenolic compounds, intense color and good tannic structure (Robinson et al., 2013; INRA, 2020). Due to its sensory characteristics, 'Marselan' has become of great importance in new world wine countries, such as China, which has the most 'Marselan' plantings in the world (Ma, 2017; Jiao and Ouijang, 2019; Lyu et al., 2019). Historically, the wine market has expanded when unfamiliar grape varieties are associated with non-traditional elaboration processes (Ostapenko et al., 2017).

Wine aromas from the 'Marselan' grape consist of black fruits, spices, cocoa and vegetal characteristics (INRA, 2020). The latter is due to the crossing of 'Cabernet Sauvignon' and 'Grenache' (Miele and Rizzon, 2011). The study of volatile composition of 'Marselan' wines was found in two scientific articles. Lyu et al. (2019) characterized the key aromatic compounds in 'Marselan' wines. The researchers found 43 odor-active compounds. The aroma profile can be described with notes such as blackberry, green pepper, honey, raspberry, caramel, smoke, and cinnamon.

Ostapenko et al. (2017) studied the sensory and chemical attributes of dessert wines created by various freezing methods of 'Marselan' grapes. The aroma profile can be characterized as fruity (pear, plum and apricots), citrus, nutty tones, with hints of spice, caramel and honey.

The winemaking process is a crucial step to define the quality of wines. It has a major influence on the main volatile compounds and their precursors. Factors such as maceration time, extraction rates, hydrolysis and oxidation influence the aromatic characteristics of wines (Guerra, 2002), and help to create distinct wines in the market. In classic winemaking, the must is collected by destemming and crushing the grapes (Baiano et al., 2016). The must remains in contact with the skins and seeds for an extended period of time in stainless steel tanks. The time allotted for this maceration will depend on the quality of the raw material and desired characteristics for the final wine (Guerra, 2002; Baiano et al., 2016).
During the integrale vinification method, the must and solid parts are placed in oak barrels, where the vinification process occurs. This method promotes greater harmony between wine and wood (Gagliole, 2013). Integrale vinification gives greater volume and depth to wines by the smooth extraction of compounds through prolonged contact with alcohol in small barrels (Gagliole, 2013).

Thermovinification is the basic principle of heating grapes at temperatures close to boiling. Once the grapes are destemmed and crushed, they are heated to temperatures between $80^{\circ} \mathrm{C}$ and $85^{\circ} \mathrm{C}$, then cooled to $35{ }^{\circ} \mathrm{C}$ or $40{ }^{\circ} \mathrm{C}$. This sudden temperature shock increases the extraction of compounds (Wang et al., 2016). The effectiveness of the process depends on the temperature regulation and grape variety. Some varieties are better adapted for thermovinification than others (Baiano et al., 2016).

The ultrasound technique uses ultrasonic energy on the grapes. This causes the physical effect of acoustic cavitation; the formation, collapsing and explosion of micro bubbles $(100 \mu \mathrm{m})$ in a localized hotspot. Acoustic cavitation produces a high amount of energy and pressure, generating shock waves, which cause cellular rupture. Due to the acoustic transmission, an increase of mass transfer rates occurs, increasing the diffusion of the compounds (Mason, 1998; Toma et al., 2001; Ferraretto and Celotti, 2016).

Some studies show analysis of red wines made by different technologies (Mihnea et al., 2014; Geffroy et al., 2015; Ostapenko et al., 2017; De Castilhos et al., 2019). However, there are no studies analyzing 'Marselan' red winemaking with the aforementioned processes. Due to the lack of research, this work is focused on the application of different winemaking processes, such as integrale vinification (IV), thermovification (TV), classic winemaking $(\mathrm{CW})$ and classic winemaking pretreated with ultrasound application (CWUS) to examine the influence on volatile composition and sensorial quality on 'Marselan' red wines. The research questions are, "Do different winemaking processes cause change in the volatile composition of wines? If so, what would be the best winemaking process?".

\section{MATERIAL AND METHODS}

\section{Samples}

Grapes: Fresh, healthy, and ripe $\left({ }^{\circ}\right.$ Brix between 23 and 25) 'Marselan' (Vitis vinifera L.) grapes were obtained from Villaggio Grando Winery, located in Água Doce city, Santa Catarina, Brazil (Latitude 2643'31.73's; Longitude $51^{\circ} 30^{\prime} 35.699$ ' 'W; Altitude $1250.22 \mathrm{~m}$ ). The harvest was completed in 
March of 2018. The harvested grapes were immediately transported from the vineyard to Embrapa in refrigerated vehicles. The grape bunches had an average weight of $100 \mathrm{~g}$ to $150 \mathrm{~g}$.

Vineyard characteristics: i) guyot pruning method (remaining number of nodes per vine after pruning was between 6 and 8); ii) elevation - first trellis wire $1.10 \mathrm{~m}$; second trellis wire $1.53 \mathrm{~m}$; iii) canopy management practices - shoot topping performed 2 or 3 times per year; iv) pest management program treatments only when raining (as required); v) fertilization program - annual limestone additions depending on soil analysis (1000 kg of limestone per hectare) the required amount of NPK fertilizers is applied and no irrigation system is used; vi) vine slope - $100 \%$ absolute North-South; vii) soil type oxisol with an average depth of $7 \mathrm{~m}$; viii) rootstock variety - Paulsen 1104; ix) vine spacing - $1.1 \mathrm{~m}$ between plants and $2.8 \mathrm{~m}$ between rows; $\mathrm{x}$ ) timing of key phenological stages - the pruning occurs between June and July and harvest occurs between 20 February and 20 April; xi) average age of the vines 22 years.

Climate conditions: i) average rainfall - $1433 \mathrm{~mm}$; ii) annual sunshine - from $2045 \mathrm{~h}$ to $2523 \mathrm{~h}$; iii) relative humidity $-77.3 \%$; iv) average temperature $-14.6{ }^{\circ} \mathrm{C}$.

\section{Winemaking processes}

Wines were elaborated in the Embrapa Grape and Wine Research Center, located in the city of Bento Gonçalves, Rio Grande do Sul, Brazil. Four winemaking processes were applied to 'Marselan' grapes during the 2018 harvest; exclusive of any impact from vintage variations since the aim of this work is to understand the impact of the winemaking processes. Four treatments were prepared; as a result of one properly controlled vinification per treatment. The vinifications were conducted by experienced winemakers and all analyses were performed three times:

i) Classic winemaking $(\mathrm{CW}): 21 \mathrm{~kg}$ of grapes were destemmed and crushed (destemmer - crushing Enoveneta - model 40) and pressed (Ricefer specially designed for small volumes) in a stainless steel tank and macerated for 10 days at $25{ }^{\circ} \mathrm{C}$. After this stage, the "drawing off" phase was completed and the fermentation began. Active dry yeast was used in the form of Saccharomyces cerevisiae (RX-60 Lallemand) at a rate of 30 $\mathrm{g} / \mathrm{hL}$. The yeast was diluted in a must aliquot for each vinification process and added to each fermentation vessel. Homogenization took place in a climate controlled room at $20^{\circ} \mathrm{C}$ for 10 days. No fermentation activator or pectinolytic enzymes were added to the must. The initial concentration of $\mathrm{SO}_{2}$ was $80 \mathrm{mg} / \mathrm{L}$. After the fermentation, a cold stabilization lasted for 15 days at $5{ }^{\circ} \mathrm{C}$. All winemaking process showed an average yield of $60 \%$.

ii) Integrale vinification (IV): $76 \mathrm{~kg}$ of 'Marselan' grapes were destemmed, crushed (the same process as in classic winemaking) and macerated for 10 days at $25^{\circ} \mathrm{C}$ in previously used 12 month old oak barrels (Quercus robur L.). The fermentation time was 10 days. A total of $50 \mathrm{~L}$ was processed. After maceration, the "drawing off" phase was completed. The fermentation continued in a stainless steel tank located in a climate controlled room at $20{ }^{\circ} \mathrm{C}$. The remaining steps in the process were the same as the Classic Winemaking method.

iii) Thermovinification (TV): $76 \mathrm{~kg}$ of grapes were destemmed and crushed (the same process as in classic winemaking). The grapes were divided into two batches of equal volume and processed the same way (Suquificador Integral SI $70 \mathrm{~kg}$ BR 10 2016002718-7) as to not overload the equipment. The grapes were placed in the equipment and heated to $90{ }^{\circ} \mathrm{C}$. Then, the must was transferred to stainless steel tanks, and cooled to $20{ }^{\circ} \mathrm{C}$. The duration of the fermentation period was 7 days. A total of $50 \mathrm{~L}$ was processed. The remaining steps of the process were the same as the Classic Winemaking method.

iv) Classic winemaking with ultrasound application (CWUS): After the grapes were destemmed and crushed $-25 \mathrm{~kg}$ - (the same process as in classic winemaking), the solid mass and part of the liquid (approximately $8 \mathrm{~L}$ of liquid was removed to decrease the number of batches) were subjected to ultrasonic treatment in an ultrasound bath for 30 minutes at $25{ }^{\circ} \mathrm{C}$ in 2 batches of $8.5 \mathrm{~kg}$ each (Thornton $\AA$, model T50; Power: $127 \mathrm{~W}$; Frequency: $40 \mathrm{kHz}$; Dimensions: $30 \mathrm{~cm} \mathrm{x} 50 \mathrm{~cm} \mathrm{x}$ $20 \mathrm{~cm}$ ). The remaining steps of the process were the same as the Classic Winemaking method.

All the wines were bottled in $375 \mathrm{~mL}$ bottles, labeled and stored in a climate controlled room regulated to $18^{\circ} \mathrm{C}$ until analysis was completed one year later. All other variables were properly controlled.

\section{Physicochemical analyses}

The oenological parameters were analyzed following the OIV methodology (OIV, 2019). The density was measured by densimetry. Total acidity was determined by potentiometric titration, and was expressed as $\mathrm{g} / \mathrm{L}$ of tartaric acid. Volatile acids were separated from the wine by steam distillation and 
titrated using standard sodium hydroxide; the result was expressed in $\mathrm{g} / \mathrm{L}$ of acetic acid. The alcoholic strength by volume was measured through distillation. The $\mathrm{pH}$ level was determined by potentiometry. The total dry extract was calculated indirectly from the specific gravity of the alcohol-free wine. Sugar levels were reduced by measuring the reaction of the clarified wine with a specified quantity of an alkaline copper salt solution; the excess copper ions were then determined iodometrically. Free and total sulfur dioxide was measured by titrimetry.

\section{Volatile compounds analysis}

The analysis followed the protocol described by Bernardi et al. (2014) with some modifications. Extraction of volatile organic compounds (VOCs) of 'Marselan' red wines was carried out by HS-SPME; using a fiber divinylbenzene/carboxen/polydimethylsiloxane $(\mathrm{DVB} / \mathrm{Car} / \mathrm{PDMS}, 50 / 30 \mu \mathrm{m} \times 20 \mathrm{~mm}$ ) under the following conditions: sample at $35{ }^{\circ} \mathrm{C}$ for 45 minutes with continuous stirring ( $500 \mathrm{rpm}$ ) with $30 \%$ of $\mathrm{NaCl}$. The fiber was purchased from Supelco (Bellefonte, PA, USA). Before its first use, the fiber was thermally conditioned in accordance with manufacturer recommendations. In all of the experiments, a $2 \mathrm{~mL}$ aliquot of wine was transferred to a $20 \mathrm{~mL}$ glass vial and the extraction was performed while constantly being stirred. Before each analysis, the mixture was carefully shaken to dissolve the salt and left to equilibrate for 5 minutes.

Volatile compounds were desorbed from the fiber and moved into a split injector (Varian 3400CX gas chromatography equipped with flame ionization detector - GC/FID) at $230{ }^{\circ} \mathrm{C}$ for $10 \mathrm{~min}$. The injector operated in splitless mode for 1 minute with an SPME liner $(0.75 \mathrm{~mm}$ i.d. $)$. The temperature of the injector and FID was set to $250^{\circ} \mathrm{C}$. Hydrogen carrier gas was added at an initial flow rate of $2 \mathrm{~mL} / \mathrm{min}$ (constant pressure of $69 \mathrm{kPa}$ ). A ZB-Wax plus capillary column was used with the dimensions of $30 \mathrm{~m} \times 0.25 \mathrm{~mm} \times$ $0.25 \mu \mathrm{m}$ film thickness (Phenomenex, Palo Alto, CA, USA). The oven temperature was set to $35^{\circ} \mathrm{C}$ for 2 minutes, raised to $80{ }^{\circ} \mathrm{C}$ for $2{ }^{\circ} \mathrm{C} / \mathrm{min}, 150{ }^{\circ} \mathrm{C}$ for 4 ${ }^{\circ} \mathrm{C} / \mathrm{min}, 230{ }^{\circ} \mathrm{C}$ for $8{ }^{\circ} \mathrm{C} / \mathrm{min}$ and maintained at this temperature for 5 minutes. For semi-quantification, the VOC concentration was calculated by internal standardization, using 3-octanol (Sigma Aldrich, Germany) at a concentration of $1.03 \mathrm{mg} / \mathrm{L}$. The response factor between internal standard and analytes was assumed as one. All analyses were carried out in triplicate and the results were expressed as $\mu \mathrm{g} / \mathrm{L}$ or the equivalent of IS.

Volatile compounds were identified with Shimadzu QP2010 Plus gas chromatography coupled with a mass spectrometer (GC/MS). GC conditions were the same as those used for the GC-FID chromatographic analysis with polar column. Helium was used as a carrier gas at a flow rate of $2 \mathrm{~mL} / \mathrm{min}$. MS was operated in electron ionization (EI) mode at $70 \mathrm{eV}$, scanning from $\mathrm{m} / \mathrm{z} 35$ to 350 . The volatile compounds were tentatively identified by comparing their mass spectra to commercial spectra databases (NIST 14), and by comparing their experimental retention index (RI) with the literature.

\section{Sensorial Analysis}

A variation of the Quantitative Descriptive Analysis (QDA) as the consensus training method was employed. Fourteen judges from Embrapa Grape and Wine, Brazil, tasted the wine samples three times with reference standards in two sessions. Six samples were evaluated per session with some modifications (1 hour per session) as reported by De Castilhos et al. (2019). All judges have experience in sensory analysis. The analysis began with a discussion regarding the attributes of the wines. The session president wrote down all of the aromatic descriptors found by the judges to generate a protocol. The generated protocol served as the basis for generating the evaluation form. Before each session, a training session was held with aromatic and flavor standards of wines available to the judges.

A discussion with the judges resulted in organizing wine attributes into seven total odor descriptors: aroma intensity, aroma multiplicity/complexity, fruit aroma, vegetal aroma, overmaturation aroma, spice aroma and undesirable aroma.

The evaluation session took place in a sensory analysis room equipped with individual cabins under daylight at ambient temperature. $40 \mathrm{~mL}$ aliquots of the analyzed wines were offered to the judges in a wine glass coded with three random digits in a random order. For each sample, the subject rated the intensity of these descriptors on a $90 \mathrm{~mm}$ electronic scale read left to right, "no odor perceived" to "very intense".

The Ethical Issues regarding the QDA was approved by the Ethics in Research Committee of the Federal University of Rio Grande do Sul (protocol $\mathrm{n}^{\circ}$. 25063519.5.0000.5347).

\section{Statistical Analysis}

The data from the volatile and sensory analyses was analyzed using one-way Analysis of Variance (ANOVA), a Tukey test $(\mathrm{p}<0.05)$ using BioEstat 5.3, and a Principal Component Analysis (PCA) (autoescaled data) using Chemostat V.2. Statistical analysis was performed after the verification of the homogeneity of variance and normality of residuals. 


\section{RESULTS AND DISCUSSION}

The physicochemical parameters of the wines are presented in Table I. All parameters lie within the identity and quality standards established by Brazilian legislation (MAPA, 2018). The parameters were presented in a similar way throughout all of the winemaking processes.

\section{Table I}

Physicochemical parameters of 'Marselan' red wines made by different winemaking processes

Parâmetros físico-químicos dos vinhos tintos 'Marselan' obtidos por diferentes processos de vinificação

\begin{tabular}{lcccc}
\hline Physicochemical parameters & TV & IV & CW & CWUS \\
\hline Density & 0.9954 & 0.9947 & 0.9958 & 0.9954 \\
Alcoholic strength by volume (\%) & 12.6 & 12.0 & 12.6 & 12.6 \\
Total acidity (g/L tartaric acid) & 8.5 & 7.3 & 7.5 & 6.9 \\
Volatile acidity (g/L acetic acid) & 1.0 & 1.2 & 1.0 & 1.0 \\
pH & 3.5 & 3.4 & 3.6 & 3.5 \\
Dry extract (g/L) & 29.0 & 25.7 & 30.0 & 29.0 \\
Reducing sugar (g/L) & 3.9 & 3.2 & 3.5 & 3.4 \\
Free sulfur dioxide (mg/L) & 41.0 & 54.4 & 69.2 & 56.4 \\
Total sulfur dioxide (mg/L) & 129.2 & 132.8 & 124.0 & 143.6
\end{tabular}

TV - Thermovinification; IV - Integrale Vinification; CW - Classic winemaking; CWUS - Classic winemaking with ultrassound application.

Sixty-three volatile compounds were tentatively identified and semi-quantified. The volatile compounds belong to different chemical groups such as esters, ketones, acids, alcohols, terpenes, volatile phenols and sulfur compounds. The identified and semi-quantified compounds are shown in Table II. The main groups of volatile compounds found in this work were esters, alcohols and acids.

Esters develop from yeast metabolism during fermentation or naturally in grape berries (Perestrelo et al., 2006; Vilanova et al., 2013). The vinification process should have been the only factor to cause differences among the four wines since the grape and yeast used during fermentation remained constant throughout the study. Moreover, possible interactions between matrix and volatile compounds may increase or decrease flavor perception (Lorrain et al., 2013). The majority compounds are ethyl acetate, isoamyl acetate, ethyl hexanoate, ethyl lactate, ethyl octanoate, ethyl decanoate and diethyl succinate. In general, these compounds showed higher concentrations in TV. Diethyl succinate and ethyl lactate were exceptions to this observation. Diethyl succinate and ethyl lactate were below the concentration threshold. For ethyl acetate and ethyl hexanoate, the concentrations were higher than the odor threshold. IV presented below the odor threshold for isoamyl acetate and ethyl decanoate, and presented above this value with TV (Peinado et al.,
2004; Fariña et al., 2015). For minority esters, there was variation between the winemaking processes, which was better observed by chemometric analysis.

Alcohols are an important group of volatile compounds in wine. The main alcohols identified in our study were isobutyl alcohol, isopentyl alcohol, hexanol and phenylethyl alcohol, showing higher concentrations in IV and CWUS wines. The presence of C6 compounds, such as 1-hexanol and (E)3-hexen1-ol, were observed. These compounds contribute to vegetal characteristics in wine (Gómez et al., 1995; Vilanova et al., 2013). (E)3-hexen-1-ol did not show significant differences between the winemaking processes and 1-hexanol, presented higher concentrations in CWUS and CW processes. Both did not reach the odor threshold (Guth, 1997).

Seven acids were identified. The majority of compounds were composed of acetic and octanoic acids, which did not exceed the odor threshold (Guth, 1997; Dominguez and Agosin, 2010). At low concentrations, acids improve aroma quality and complexity (Shinohara, 1985; Fariña et al., 2015).

Statistical analysis was carried out to better distinguish the wines made by different winemaking processes due to the large number of variables present in this study. Considering that few variables hold the most important chemical information, the Principal Component Analysis (PCA) was used to provide fast 
Table II

Volatile profile of 'Marselan' red wines detected by GC-FID and GC-MS with retention index, mean concentration and standard deviation Perfil volátil dos vinhos tintos 'Marselan' detectados via GC-FID e GC-MS, contendo indice de retenção, concentração média e desvio padrão

\begin{tabular}{|c|c|c|c|c|c|c|}
\hline & Compound Name & $\begin{array}{c}\text { TV } \\
(\mu \mathrm{g} / \mathrm{L})\end{array}$ & $\underset{(\mu \mathrm{g} / \mathrm{L})}{\mathrm{IV}}$ & $\begin{array}{c}\mathbf{C W} \\
(\mu \mathrm{g} / \mathrm{L})\end{array}$ & $\begin{array}{c}\text { CWUS } \\
(\mu \mathrm{g} / \mathrm{L})\end{array}$ & KI ZB-WAX \\
\hline $\mathbf{K}$ & Ketones & & & & & \\
\hline K1 & Acetone & $9.7 \pm 0.5^{\mathrm{a}}$ & $5.0 \pm 0.4^{b}$ & $8.1 \pm 0.5^{\mathrm{a}}$ & $8.8 \pm 1.3^{\mathrm{a}}$ & 809 \\
\hline $\mathbf{K 2}$ & 2,3-Butanedione & $17.8 \pm 1.2^{\mathrm{a}}$ & $17.6 \pm 2.6^{\mathrm{a}}$ & $19.3 \pm 1.4^{\mathrm{a}}$ & $31.5 \pm 4.6^{\mathrm{b}}$ & 946 \\
\hline $\mathbf{K 3}$ & 3-Octanone & $20.0 \pm 0.5^{\mathrm{a}}$ & $21.4 \pm 0.7^{\mathrm{a}}$ & $21.7 \pm 0.3^{\mathrm{a}}$ & $20.1 \pm 1.3^{\mathrm{a}}$ & 1245 \\
\hline $\mathrm{K} 4$ & Cis-Geranylacetone & $8.8 \pm 1.1^{\mathrm{a}}$ & $9.1 \pm 0.4^{\mathrm{a}}$ & $10.3 \pm 0.6^{\mathrm{a}}$ & $9.8 \pm 0.4^{\mathrm{a}}$ & 1869 \\
\hline $\mathbf{E}$ & Esters & & & & & \\
\hline E1 & Ethyl acetate & $1115 \pm 55.3^{\mathrm{a}}$ & $1193 \pm 128.9^{\mathrm{a}}$ & $903.8 \pm 29.4^{b}$ & $860.9 \pm 12.2^{\mathrm{b}}$ & 895 \\
\hline E2 & Ethyl 2-methyl-propanoate & $62.3 \pm 3.6^{\mathrm{a}}$ & $38.2 \pm 1.5^{\mathrm{b}}$ & $36.7 \pm 3.4^{\mathrm{bc}}$ & $74.4 \pm 8.7^{\mathrm{a}}$ & 936 \\
\hline $\mathbf{E 3}$ & n-Propyl acetate & $31.7 \pm 2.3^{\mathrm{a}}$ & $19.3 \pm 1.2^{\mathrm{b}}$ & $27.5 \pm 1.1^{\mathrm{ab}}$ & $39.4 \pm 7.7^{\mathrm{a}}$ & 942 \\
\hline E4 & Isobutyl acetate & $5.1 \pm 0.5^{\mathrm{abc}}$ & $5.5 \pm 0.6^{\mathrm{b}}$ & $3.9 \pm 0.1^{\mathrm{c}}$ & $3.8 \pm 0.3^{\mathrm{abc}}$ & 971 \\
\hline E5 & Ethyl butanoate & $2.3 \pm 0.3^{\mathrm{a}}$ & $2.1 \pm 0.2^{\mathrm{a}}$ & $1.4 \pm 0.2^{\mathrm{a}}$ & $2.0 \pm 0.3^{\mathrm{a}}$ & 1010 \\
\hline E6 & Ethyl 2-methylbutanoate & $4.0 \pm 0.3^{\mathrm{a}}$ & $4.4 \pm 0.4^{\mathrm{a}}$ & $2.1 \pm 0.1^{\mathrm{b}}$ & $3.0 \pm 0.4^{\mathrm{ab}}$ & 1029 \\
\hline E7 & Isoamyl acetate & $92.2 \pm 7.3^{\mathrm{a}}$ & $10.3 \pm 0.6^{b}$ & $69.5 \pm 1.3^{\mathrm{c}}$ & $57.8 \pm 7.0^{\text {cd }}$ & 1102 \\
\hline E8 & Methyl hexanoate & $1.5 \pm 0.1^{\mathrm{a}}$ & $1.3 \pm 0.1^{\mathrm{a}}$ & $0.8 \pm 0.1^{\mathrm{a}}$ & $1.4 \pm 0.1^{\mathrm{a}}$ & 1178 \\
\hline E9 & Ethyl hexanoate & $146.5 \pm 14.9^{\mathrm{a}}$ & $128.8 \pm 7.8^{\mathrm{ab}}$ & $111.6 \pm 2.3^{\mathrm{b}}$ & $120.6 \pm 11.8^{\mathrm{ab}}$ & 1230 \\
\hline E10 & Hexyl acetate & $6.3 \pm 0.6^{\mathrm{a}}$ & $5.2 \pm 0.1^{\mathrm{a}}$ & $3.0 \pm 0.2^{\mathrm{b}}$ & $2.5 \pm 0.2^{\mathrm{bc}}$ & 1266 \\
\hline E11 & Ethyl heptanoate & $2.0 \pm 0.2^{\mathrm{a}}$ & $2.5 \pm 0.3^{\mathrm{a}}$ & $2.0 \pm 0.2^{\mathrm{a}}$ & $2.4 \pm 0.2^{\mathrm{a}}$ & 1323 \\
\hline E12 & Ethyl 2-hexenoate & $9.0 \pm 0.2^{\mathrm{a}}$ & $8.3 \pm 0.5^{\mathrm{a}}$ & $1.8 \pm 0.2^{\mathrm{b}}$ & $1.5 \pm 0.1^{\mathrm{bc}}$ & 1330 \\
\hline E13 & Ethyl lactate & $112.8 \pm 6.4^{\mathrm{a}}$ & $93.4 \pm 8.7^{\mathrm{b}}$ & $136.1 \pm 4.2^{\mathrm{c}}$ & $155.9 \pm 3.5^{\mathrm{d}}$ & 1340 \\
\hline E14 & Methyl octanoate & $2.0 \pm 0.1^{\mathrm{a}}$ & $1.7 \pm 0.01^{\mathrm{a}}$ & $2.2 \pm 0.2^{\mathrm{a}}$ & $2.9 \pm 0.2^{\mathrm{a}}$ & 1380 \\
\hline E15 & Ethyl octanoate & $483.4 \pm 70.3^{\mathrm{a}}$ & $365.0 \pm 33.0^{\mathrm{b}}$ & $237.7 \pm 13.9^{\mathrm{c}}$ & $284.8 \pm 43.6^{\mathrm{bc}}$ & 1434 \\
\hline E16 & Isoamylhexanoate & $2.7 \pm 0.1^{\mathrm{a}}$ & $3.8 \pm 0.4^{\mathrm{b}}$ & $5.0 \pm 0.3^{\mathrm{c}}$ & $4.3 \pm 0.2^{\mathrm{bc}}$ & 1480 \\
\hline E17 & Ethyl 3-hydroxybutanoate & $2.8 \pm 0.3^{\mathrm{a}}$ & $2.3 \pm 0.01^{\mathrm{a}}$ & $2.3 \pm 0.1^{\mathrm{a}}$ & $1.7 \pm 0.1^{\mathrm{a}}$ & 1519 \\
\hline E18 & Ethyl nonanoate & $2.2 \pm 0.1^{\mathrm{a}}$ & $2.0 \pm 0.3^{\mathrm{a}}$ & $2.6 \pm 0.1^{\mathrm{a}}$ & $2.5 \pm 0.1^{\mathrm{a}}$ & 1527 \\
\hline E19 & Ethyl 2-hydroxyhexanoate & $35.1 \pm 3.8^{\mathrm{a}}$ & $18.0 \pm 2.4^{\mathrm{b}}$ & $32.6 \pm 3.0^{\mathrm{a}}$ & $36.3 \pm 3.0^{\mathrm{a}}$ & 1543 \\
\hline E20 & Ethyl 3-(methylthio)propionate & $9.6 \pm 0.9^{\mathrm{a}}$ & $9.9 \pm 0.01^{\mathrm{a}}$ & $10.7 \pm 0.7^{\mathrm{a}}$ & $12.8 \pm 1.3^{\mathrm{b}}$ & 1570 \\
\hline E21 & Isoamyl lactate & $3.5 \pm 0.3^{\mathrm{a}}$ & $3.0 \pm 0.4^{\mathrm{ab}}$ & $4.1 \pm 0.5^{\mathrm{ac}}$ & $5.0 \pm 0.4^{\mathrm{c}}$ & 1573 \\
\hline E22 & Ethyl 2-furancarboxylate & $11.5 \pm 1.0^{\mathrm{a}}$ & $12.2 \pm 0.6^{\mathrm{a}}$ & $8.7 \pm 0.5^{\mathrm{b}}$ & $8.8 \pm 1.0^{\mathrm{b}}$ & 1620 \\
\hline E23 & Ethyl decanoate & $206.5 \pm 21.8^{\mathrm{a}}$ & $122.9 \pm 14.2^{\mathrm{b}}$ & $56.9 \pm 3.0^{\mathrm{c}}$ & $84.5 \pm 5.8^{\mathrm{c}}$ & 1640 \\
\hline E24 & Ethyl benzoate & $16.9 \pm 1.0^{\mathrm{a}}$ & $13.0 \pm 1.6^{\mathrm{ab}}$ & $8.3 \pm 0.2^{\mathrm{bc}}$ & $8.3 \pm 0.5^{\mathrm{cd}}$ & 1664 \\
\hline E25 & Diethyl succinate & $226.2 \pm 16.6^{\mathrm{a}}$ & $227.9 \pm 15.3^{\mathrm{a}}$ & $489.2 \pm 45.4^{\mathrm{b}}$ & $398.9 \pm 5.9^{\mathrm{c}}$ & 1683 \\
\hline E26 & Ethyl benzeneacetate & $16.7 \pm 1.0^{\mathrm{a}}$ & $21.1 \pm 0.5^{\mathrm{b}}$ & $7.5 \pm 0.3^{\mathrm{c}}$ & $7.2 \pm 0.3^{\mathrm{c}}$ & 1786 \\
\hline E27 & Ethyl myristate & $4.1 \pm 0.1^{\mathrm{a}}$ & $3.8 \pm 0.6^{\mathrm{ac}}$ & $2.1 \pm 0.1^{\mathrm{b}}$ & $3.7 \pm 0.1^{\mathrm{c}}$ & 2063 \\
\hline E28 & Ethyl pentadecanoate & $2.3 \pm 0.2^{\mathrm{a}}$ & $2.2 \pm 0.1^{\mathrm{a}}$ & $2.2 \pm 0.2^{\mathrm{a}}$ & $2.7 \pm 0.01^{\mathrm{a}}$ & 2191 \\
\hline E29 & Ethyl hexadecanoate & $45.1 \pm 5.0^{\mathrm{a}}$ & $45.5 \pm 7.0^{\mathrm{a}}$ & $15.1 \pm 2.1^{\mathrm{b}}$ & $21.8 \pm 1.6^{\mathrm{b}}$ & 2285 \\
\hline E30 & Ethyl hydrogen succinate & $2.6 \pm 0.2^{\mathrm{a}}$ & $3.2 \pm 0.3^{\mathrm{ab}}$ & $2.0 \pm 0.1^{\mathrm{ac}}$ & $1.8 \pm 0.1^{\mathrm{ac}}$ & 2350 \\
\hline E31 & $\begin{array}{l}\text { Methyl stearate } \\
\text {. }\end{array}$ & $14.2 \pm 1.6^{\mathrm{a}}$ & $12.7 \pm 1.7^{\mathrm{a}}$ & $24.9 \pm 4.5^{\mathrm{b}}$ & $28.8 \pm 3.9^{\mathrm{b}}$ & 2401 \\
\hline
\end{tabular}


Table II

(continued)

\begin{tabular}{|c|c|c|c|c|c|c|}
\hline & Compound Name & $\underset{(\mu \mathrm{g} / \mathrm{L})}{\text { TV }}$ & $\underset{(\mu \mathrm{g} / \mathrm{L})}{\mathbf{I V}}$ & $\begin{array}{c}\mathbf{C W} \\
(\mu \mathrm{g} / \mathbf{L})\end{array}$ & $\begin{array}{l}\text { CWUS } \\
(\mu \mathrm{g} / \mathrm{L})\end{array}$ & KI ZB-WAX \\
\hline $\mathbf{H}$ & Alcohols & & & & & \\
\hline H1 & Isobutyl alcohol & $273.5 \pm 12.6^{\mathrm{abc}}$ & $313.6 \pm 24.0^{\mathrm{b}}$ & $251.5 \pm 10.2^{\mathrm{c}}$ & $285.5 \pm 6.6^{\mathrm{abc}}$ & 1077 \\
\hline $\mathrm{H} 2$ & Butyl alcohol & $8.4 \pm 0.4^{\mathrm{a}}$ & $6.3 \pm 0.6^{\mathrm{b}}$ & $11.0 \pm 0.4^{\mathrm{c}}$ & $12.0 \pm 0.4^{\mathrm{c}}$ & 1136 \\
\hline $\mathbf{H 3}$ & Isopentyl alcohol & $3154 \pm 186.3^{\mathrm{a}}$ & $3500 \pm 273.3^{\mathrm{ab}}$ & $2943 \pm 132.4^{\mathrm{a}}$ & $3574 \pm 74.4^{\mathrm{ab}}$ & 1216 \\
\hline H4 & 2-Heptanol & $2.5 \pm 0.1^{\mathrm{a}}$ & $2.0 \pm 0.01^{\mathrm{a}}$ & $4.9 \pm 0.2^{\mathrm{b}}$ & $5.9 \pm 0.1^{\mathrm{b}}$ & 1318 \\
\hline $\mathrm{H5}$ & 1-Hexanol & $231.9 \pm 13.0^{\mathrm{a}}$ & $220.4 \pm 16.9^{\mathrm{a}}$ & $281.0 \pm 12.1^{\mathrm{b}}$ & $313.2 \pm 5.4^{\mathrm{b}}$ & 1351 \\
\hline H6 & (E)3-hexen-1-ol & $2.5 \pm 0.1^{\mathrm{a}}$ & $2.6 \pm 0.4^{\mathrm{a}}$ & $3.4 \pm 0.2^{\mathrm{a}}$ & $4.2 \pm 0.01^{\mathrm{a}}$ & 1360 \\
\hline H7 & 1-Octen-3-ol & $33.4 \pm 1.1^{\mathrm{a}}$ & $26.9 \pm 3.1^{\mathrm{b}}$ & $34.4 \pm 0.6^{\mathrm{a}}$ & $48.3 \pm 2,5^{\mathrm{c}}$ & 1462 \\
\hline $\mathrm{H8}$ & 2-Ethyl-hexyl alcohol & $2.3 \pm 0.1^{\mathrm{a}}$ & $1.7 \pm 0.3^{\mathrm{a}}$ & $2.0 \pm 0.1^{\mathrm{a}}$ & $7.0 \pm 0.8^{b}$ & 1496 \\
\hline H9 & 2-Nonanol & $6.1 \pm 0.4^{\mathrm{a}}$ & $5.5 \pm 0.3^{\mathrm{a}}$ & $8.4 \pm 0.3^{\mathrm{b}}$ & $11.9 \pm 0.9^{\mathrm{c}}$ & 1521 \\
\hline H10 & 1-Octanol & $2.9 \pm 0.2^{\mathrm{a}}$ & $2.3 \pm 0.01^{\mathrm{a}}$ & $3.1 \pm 0.3^{\mathrm{a}}$ & $4.0 \pm 0.2^{b}$ & 1567 \\
\hline H11 & (E)2-Octen-1-ol & $15.4 \pm 1.4^{\mathrm{a}}$ & $11.9 \pm 1.4^{\mathrm{a}}$ & $29.0 \pm 2.2^{\mathrm{b}}$ & $35.1 \pm 1.8^{\mathrm{c}}$ & 1618 \\
\hline $\mathrm{H} 12$ & 1-Decanol & $7.2 \pm 0.2^{\mathrm{a}}$ & $7.2 \pm 0.7^{\mathrm{a}}$ & $6.9 \pm 0.1^{\mathrm{a}}$ & $8.1 \pm 0.8^{\mathrm{a}}$ & 1755 \\
\hline H13 & Benzyl Alcohol & $8.9 \pm 1.0^{\mathrm{a}}$ & $7.6 \pm 1.3^{\mathrm{ab}}$ & $13.2 \pm 1.4^{\mathrm{c}}$ & $12.7 \pm 0.9^{\mathrm{ac}}$ & 1882 \\
\hline H14 & Phenylethyl alcohol & $1320 \pm 114.7^{\mathrm{a}}$ & $1470 \pm 78.4^{\mathrm{a}}$ & $744.3 \pm 100.4^{b}$ & $1044 \pm 15.9^{\mathrm{c}}$ & 1919 \\
\hline $\mathbf{T}$ & Terpenes & & & & & \\
\hline T1 & Linalool & $4.6 \pm 0.5^{\mathrm{a}}$ & $4.7 \pm 0.6^{\mathrm{ab}}$ & $4.1 \pm 0.4^{\mathrm{a}}$ & $3.5 \pm 0.3^{\mathrm{ac}}$ & 1549 \\
\hline T2 & $(-)-4$-Terpineol & $7.1 \pm 0.9^{\mathrm{a}}$ & $4.3 \pm 0.7^{\mathrm{b}}$ & $11.6 \pm 0.5^{\mathrm{c}}$ & $12.0 \pm 1.3^{\mathrm{c}}$ & 1594 \\
\hline T3 & (-)-Myrtenol & $3.3 \pm 0.2^{\mathrm{a}}$ & $3.4 \pm 0.3^{\mathrm{a}}$ & $3.1 \pm 0.2^{\mathrm{ab}}$ & $2.7 \pm 0.2^{\mathrm{b}}$ & 1797 \\
\hline $\mathbf{A}$ & Acids & & & & & \\
\hline A1 & Acetic acid & $105.0 \pm 4.8^{\mathrm{a}}$ & $114.7 \pm 13.3^{\mathrm{ab}}$ & $91.1 \pm 3.1^{\mathrm{ac}}$ & $92.8 \pm 4.7^{\mathrm{ac}}$ & 1459 \\
\hline A2 & Butanoic acid & $1.9 \pm 0.2^{\mathrm{a}}$ & $2.0 \pm 0.1^{\mathrm{a}}$ & $1.9 \pm 0.01^{\mathrm{a}}$ & $2.4 \pm 0.2^{\mathrm{a}}$ & 1624 \\
\hline $\mathbf{A 3}$ & Hexanoic acid & $72.2 \pm 6.5^{\mathrm{a}}$ & $72.5 \pm 4.2^{\mathrm{a}}$ & $47.3 \pm 5.1^{\mathrm{b}}$ & $60.1 \pm 1.9^{\mathrm{ac}}$ & 1858 \\
\hline A4 & Ethylhexanoic acid & $2.4 \pm 0.1^{\mathrm{a}}$ & $1.8 \pm 0.1^{\mathrm{b}}$ & $3.1 \pm 0.1^{\mathrm{a}}$ & $2.3 \pm 0.1^{\mathrm{a}}$ & 1975 \\
\hline A5 & Octanoic acid & $179.1 \pm 15.0^{\mathrm{a}}$ & $181.8 \pm 10.2^{\mathrm{a}}$ & $72.9 \pm 9.2^{\mathrm{b}}$ & $94.7 \pm 3.6^{\mathrm{b}}$ & 2074 \\
\hline A6 & Tetradecanoic acid & $2.1 \pm 0.2^{\mathrm{a}}$ & $1.7 \pm 0.01^{\mathrm{a}}$ & $1.8 \pm 0.2^{\mathrm{a}}$ & $1.9 \pm 0.1^{\mathrm{a}}$ & 2710 \\
\hline A7 & n-Hexadecanoic acid & $3.2 \pm 0.4^{\mathrm{a}}$ & $4.8 \pm 0.7^{\mathrm{ab}}$ & $5.4 \pm 0.6^{\mathrm{b}}$ & $4.4 \pm 0.5^{\mathrm{ab}}$ & 2855 \\
\hline $\mathbf{O}$ & Others & & & & & \\
\hline 01 & Furfural & $6.8 \pm 0.1^{\mathrm{a}}$ & $6.2 \pm 0.2^{\mathrm{a}}$ & $7.9 \pm 0.2^{\mathrm{b}}$ & $7.4 \pm 0.6^{b}$ & 1490 \\
\hline 02 & Benzaldehyde & $38.6 \pm 2.5^{\mathrm{a}}$ & $28.3 \pm 0.2^{\mathrm{a}}$ & $104.2 \pm 9.9^{\mathrm{b}}$ & $140.0 \pm 5.0^{\mathrm{c}}$ & 1508 \\
\hline 03 & Methionol & $11.3 \pm 0.5^{\mathrm{a}}$ & $11.5 \pm 1.6^{\mathrm{a}}$ & $8.7 \pm 0.9^{b}$ & $9.4 \pm 0.7^{\mathrm{ab}}$ & 1718 \\
\hline 04 & 4-Ethylphenol & $3.0 \pm 0.2^{\mathrm{a}}$ & $3.0 \pm 0.4^{\mathrm{a}}$ & $1.7 \pm 0.2^{\mathrm{b}}$ & $2.5 \pm 0.2^{\mathrm{ab}}$ & 2206 \\
\hline
\end{tabular}

application; KI ZB-WAX - Experimental linear retention index on capillary column ZB-Wax; abcd - Different letters in the same row indicate significant differences ( $<<0.05$; Tukeys's test). 
and efficient information about the similarities and differences between the samples (Morgano et al., 1999).

PCA was used to better examine the compounds which underwent changes in their concentration due to the different winemaking processes applied. The PCA included only the compounds that show statistical differences (Figure 1). Of the sixty-three volatile compounds, only thirteen did not show any significant differences. PC1 and PC2 explained $88.52 \%$ of the total variance. PC1 separated CW and CWUS wines from TV and IV. PC2 separated CW and IV wines from TV and CWUS. This division was expected since CW and CWUS were elaborated in similar ways. However, the temperature applied to $\mathrm{TV}$ and the ultrasound applied to CWUS resulted in similar levels of extraction.

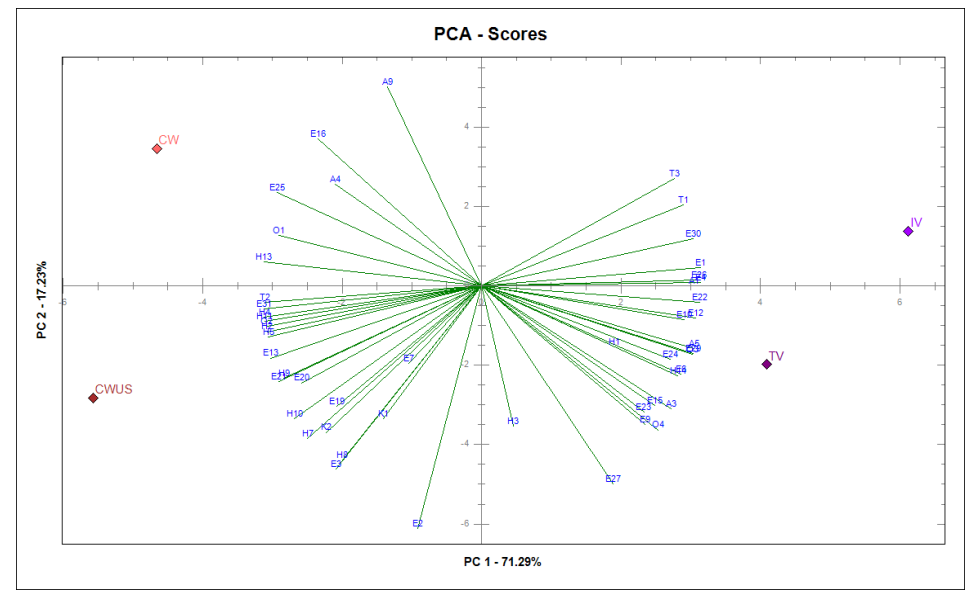

Figure 1. PCA plot of volatile compounds of 'Marselan' red wines made by different winemaking processes.

Representação da PCA dos compostos voláteis dos vinhos tintos 'Marselan' resultantes de diferentes processos de vinificação.

TV: thermovinification; IV: integrale vinification; CW: classic winemaking; CWUS: classic winemaking with ultrasound application. The legend for the volatile compounds codes can be seen in Table II.

Greater influence of ethyl esters and acetates was observed for TV. This finding coincides with the study carried out by Geffroy et al. (2015), who verified an increase in the concentration of these compounds; using similar methodology in different grape varieties. This result is expected due to applied heat during thermovinification, which causes the softening of berry peels and generates a higher probability for aromatic precursors to break. Consequently, this enables the release of more organic acids, ethyl esters and acetates contributing to a sweet and fruity aroma. Different esters, even at low concentrations, can cause changes in the aroma of wines (Pineau, 2007) supporting the slight variations found in some compounds in this work. Compounds such as isobutyl acetate and ethyl-3hydroxybutanoate were identified as an indirect influence on the aroma of wines, even at low concentrations (Lytra et al., 2013). Throughout this research, these compounds presented higher concentrations in the TV and CWUS wines, further explaining their strong fruity characteristics.
CWUS presented greater influence on alcohols. This result is consistent with the study performed by Plaza et al. (2019). The application of ultrasound causes changes such as extraction of bioactive compounds in a shorter time. It also affects the volatile composition as it causes the rupture of cells and increases the rate of mass transfer of several compounds, including aroma precursors (Plaza et al., 2019).

To observe the impact of volatile compounds on wines, a quantitative descriptive sensory analysis was performed.

All of the winemaking processes resulted in a similar aroma profile among the wines (Figure 2), but some differences could be distinguished. TV and CWUS had a more similar aroma profile, with a greater perception of a fruity aroma, overmaturation aroma and aromatic intensity and complexity. Undesirable and vegetal aromas were not perceived as strongly. These perceptions were inverted for CW and IV. Significant differences were observed for vegetal and undesirable aromas. In order to obtain a better relationship between the sensory aspect and the 
different winemaking processes, a chemometric approach was used; Principal Component Analysis (PCA).

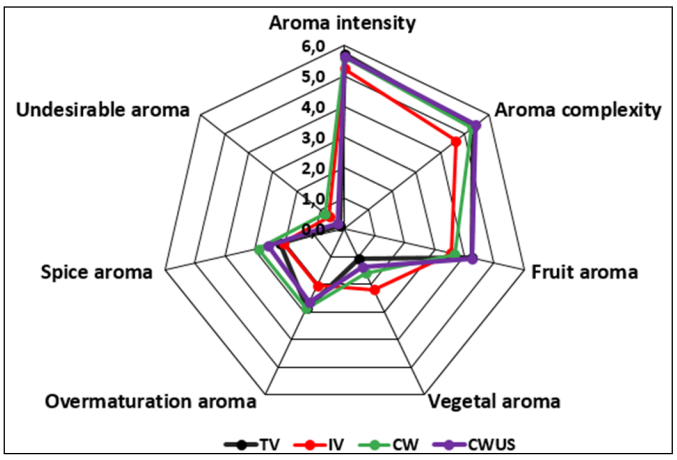

Figure 2. Sensorial profile of 'Marselan' red wines made by different winemaking processes.

Perfil sensorial dos vinhos tintos 'Marselan' obtidos por diferentes processos de vinificação.

The PCA biplot for the Quantitative Descriptive Analysis (Figure 3) revealed the following information; PC1 showed $70.05 \%$ of the total variance and PC2 showed $26.51 \%$, totaling $96.56 \%$.

PC1 separated wines from TV, CWUS, and CW from IV, while PC2 separated wines from TV, CWUS, and $\mathrm{IV}$ from $\mathrm{CW}$, demonstrating some differences between the three suggested winemaking processes and $\mathrm{CW}$. This division confirms the previous explanation of a greater influence from the fruity aroma on TV wines, aroma intensity and complexity and overmaturation aroma in CWUS wines, and vegetal and undesirable aromas in IV and $\mathrm{CW}$ wines. This division and the aromatic descriptors cited by the judges in Table III further explain the aromatic compounds found in the wines. It is important to keep in mind that the intensity of each compound depends on its concentration threshold and set of aromatic compounds.

CWUS showed similar scores to TV in sensory analysis in terms of intensity, complexity and fruity aroma profiles. Similar behavior can be explained by the ultrasound pretreatment, which causes cellular rupture and increase of mass transfer rates (Mason, 1998; Toma et al., 2001; Ferraretto and Celotti, 2016). This phenomenon can be compared with the temperature application in TV. CWUS pretreatment was more abrupt than TV, because it caused additional extraction of several other compounds, resulting in greater distinction of aromas in sensory analysis as shown in Table III. Fruity aromas and other compounds, such as ethereal conferred by alcohols, butter (2,3-butanedione) and almond (benzaldehyde) tones, give greater aromatic complexity (Zea et al., 2001; Fariña et al., 2015; Lyu et al., 2019).

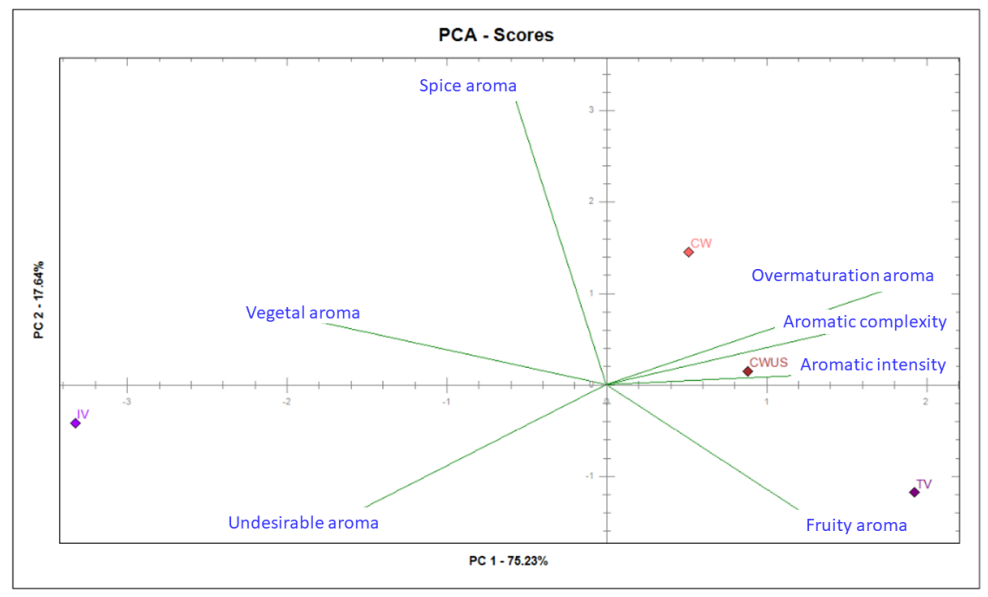

Figure 3. PCA plot of sensory analysis of 'Marselan' red wines made by different winemaking processes.

Gráfico de PCA da análise sensorial dos vinhos tintos 'Marselan' obtidos por diferentes processos de vinificação.

$\diamond \mathrm{TV}$ : thermovinification; $\$ \mathrm{IV}$ : integrale vinification; $\downarrow \mathrm{CW}$ : classic winemaking; $\diamond \mathrm{CWUS}$ : classic winemaking with ultrasound application. 
Table III

Aromatic descriptors found in the quantitative descriptive analysis cited by the judges and its prevalence

Descritores aromáticos encontrados na análise descritiva quantitativa pelos provadores e sua prevalência

\begin{tabular}{|c|c|c|c|c|c|}
\hline Vinification Technique & Fruit Aroma (\%) & Vegetal Aroma (\%) & Overmaturation Aroma (\%) & Spice Aroma (\%) & Undesirable Aroma (\%) \\
\hline Thermovinification (TV) & $\begin{array}{l}\text { Plum - 42.8 } \\
\text { Strawberry - } 16.9 \\
\text { Red fruits - } 9.5 \\
\text { Raspberry }-7.1 \\
\text { Blackberry - } 9.5 \\
\text { Cassis - } 4.7 \\
\text { Neutral - } 4.7 \\
\text { Blueberry - } 2.4 \\
\text { Guava - } 2.4\end{array}$ & $\begin{array}{l}\text { Not detected }-38 \\
\text { String bean - } 16.7 \\
\text { Bell pepper - } 14.3 \\
\text { Asparagus - } 7.1 \\
\text { Twig }-4.7 \\
\text { Broccoli }-2.4 \\
\text { Cabbage }-2.4 \\
\text { Mint }-2.4 \\
\text { Hay }-2.4 \\
\text { Herbs }-2.4 \\
\text { Eucalyptus - } 2.4 \\
\text { Pencil - } 2.4 \\
\text { Withe - } 2.4\end{array}$ & $\begin{array}{l}\text { Raisin }-33.3 \\
\text { Neutral }-21.4 \\
\text { Compote }-16.7 \\
\text { Jelly - } 9.5 \\
\text { Honey - } 9.5 \\
\text { Liqueur cassis - } 4.8 \\
\text { Vinous - } 4.8\end{array}$ & $\begin{array}{l}\text { Neutral }-35.6 \\
\text { Pepper - } 26.2 \\
\text { Cinnamon - } 12.0 \\
\text { Clove - } 7.1 \\
\text { Nutmeg }-7.1 \\
\text { Herbs - } 4.8 \\
\text { Mushroom - } 4.8 \\
\text { Vanilla - } 2.4\end{array}$ & $\begin{array}{l}\text { Not detected - } 95.2 \\
\text { Oxidized - } 2.4 \\
\text { Herbaceous - } 2.4\end{array}$ \\
\hline Integrale Vinification (IV) & $\begin{array}{l}\text { Plum - 45 } \\
\text { Neutral - } 12.5 \\
\text { Red fruits - } 10 \\
\text { Blackberry - } 7.5 \\
\text { Strawberry }-7.5 \\
\text { Cherry - } 7.5 \\
\text { Fig - 2.5 } \\
\text { Tropical fruit - } 2.5 \\
\text { Guava - } 2.5 \\
\text { Jabuticaba - } 2.5 \\
\end{array}$ & $\begin{array}{l}\text { Bell pepper - } 29.4 \\
\text { Not detected }-24.4 \\
\text { String bean }-21.9 \\
\text { Asparagus - } 4.9 \\
\text { Dry straw - } 4.9 \\
\text { Twig - } 4.9 \\
\text { Withe - } 2.4 \\
\text { Herbaceous - } 2.4 \\
\text { Grass - } 2.4 \\
\text { Coconut - } 2.4\end{array}$ & $\begin{array}{l}\text { Not detected }-35.7 \\
\text { Raisin }-33.3 \\
\text { Compote }-11.9 \\
\text { Jelly }-9.5 \\
\text { Liqueur of red fruits - } 4.8 \\
\text { Cassis }-2.4 \\
\text { Honey }-2.4\end{array}$ & $\begin{array}{l}\text { Not detected - } 26.8 \\
\text { Pepper - } 14.9 \\
\text { Mint - } 12.1 \\
\text { Clove - 9.7 } \\
\text { Cinnamon - } 7.3 \\
\text { Mushroom - } 7.3 \\
\text { Nutmeg - } 7.3 \\
\text { Fine herbs - } 4.9 \\
\text { Honey - 4.9 } \\
\text { Vanilla - 2.4 } \\
\text { Chocolate - 2.4 }\end{array}$ & $\begin{array}{l}\text { Not detected }-80.8 \\
\text { Herbaceous }-12.0 \\
\text { Twig - } 2.4 \\
\text { Oxidized }-4.8\end{array}$ \\
\hline Classic winemaking $(\mathrm{CW})$ & $\begin{array}{l}\text { Plum - 42.8 } \\
\text { Not detected - } 14.3 \\
\text { Blackberry }-11.9 \\
\text { Red fruits - } 9.5 \\
\text { Strawberry }-7.14 \\
\text { Currant - } 4.8 \\
\text { Physalis - } 2.4 \\
\text { Tropical fruit }-2.4 \\
\text { Cherry - } 2.4 \\
\text { Raspberry - } 2.4\end{array}$ & $\begin{array}{l}\text { Not detected }-40.3 \\
\text { Bell pepper }-21.4 \\
\text { String bean }-9.5 \\
\text { Dry straw }-4.8 \\
\text { Withe }-4.8 \\
\text { Broccoli }-4.8 \\
\text { Asparagus - } 4.8 \\
\text { Cabbage }-2.4 \\
\text { Pepper }-2.4 \\
\text { Twig - } 2.4 \\
\text { Mint }-2.4 \\
\end{array}$ & $\begin{array}{l}\text { Not detected }-33.4 \\
\text { Raisin }-30.9 \\
\text { Jelly }-9.5 \\
\text { Burnt coconut }-9.5 \\
\text { Honey }-7.1 \\
\text { Liqueur }-4.8 \\
\text { Grape jelly }-2.4 \\
\text { Marmalade - } 2.4\end{array}$ & $\begin{array}{l}\text { Pepper - } 30.9 \\
\text { Clove - } 19.1 \\
\text { Not detected - } 14.3 \\
\text { Cinnamon - } 9.5 \\
\text { Herbs - } 9.5 \\
\text { Mint - } 7.1 \\
\text { Mushroom - } 4.8 \\
\text { Nutmeg - } 2.4 \\
\text { Burnt coconut - } 2.4\end{array}$ & $\begin{array}{l}\text { Not detected - } 76.1 \\
\text { Herbaceous - } 14.3 \\
\text { Resin - } 2.4 \\
\text { Reduced wine - } 2.4 \\
\text { Burnt wine - } 2.4 \\
\text { Twig - } 2.4\end{array}$ \\
\hline $\begin{array}{l}\text { Classic winemaking with } \\
\text { ultrasound application (CWUS) }\end{array}$ & $\begin{array}{l}\text { Plum - 40.5 } \\
\text { Blackberry - } 21.4 \\
\text { Strawberry - } 14.3 \\
\text { Raspberry - } 7.0 \\
\text { Red fruits - } 4.8 \\
\text { Not detected - } 4.8 \\
\text { Cherry - } 2.4 \\
\text { Currant - 2.4 } \\
\text { Cassis - 2.4 }\end{array}$ & $\begin{array}{l}\text { Not detected }-45.1 \\
\text { Asparagus - } 14.3 \\
\text { String bean }-12 \\
\text { Bell pepper - } 9.5 \\
\text { Twig - } 7.1 \\
\text { Dry straw - } 4.8 \\
\text { Grass - } 2.4 \\
\text { Pepper - } 2.4 \\
\text { Coriander - } 2.4\end{array}$ & $\begin{array}{l}\text { Raisin - 35.6 } \\
\text { Not detected - } 26.2 \\
\text { Jelly - } 9.5 \\
\text { Honey - } 7.1 \\
\text { Compote - } 7.1 \\
\text { Liqueur - } 4.8 \\
\text { Marmalade - } 4.9 \\
\text { Cassis - 2.4 } \\
\text { Grape jelly - } 2.4\end{array}$ & $\begin{array}{l}\text { Pepper - 26.0 } \\
\text { Not detected - } 19.0 \\
\text { Cinnamon - } 14.3 \\
\text { Clove - } 12 \\
\text { Nutmeg - } 7.1 \\
\text { Mint - 4.8 } \\
\text { Vanilla - } 4.8 \\
\text { Herbs - } 4.8 \\
\text { Prune - 2.4 } \\
\text { Leather - 2.4 } \\
\text { Mushroom - } 2.4 \\
\end{array}$ & $\begin{array}{l}\text { Not detected }-85.8 \\
\text { Herbaceous }-12.0 \\
\text { Resin }-2.2\end{array}$ \\
\hline
\end{tabular}


Undesirable and vegetal aromas had a greater influence on IV and CW due to the higher perception of sulfurous and green aromas. This result proves that small differences in the concentration of certain compounds can greatly influence the final aromas of wine, since these two wines had less influence from esters.

It is important to highlight that IV wine should have given the perception of a spice character since it was the only wine to undergo contact with an oak barrel. The absence of the spice aroma could be linked to the brief length of time the wine was in contact with wood. The aroma profile of IV wine may be a result of different extraction rates, oxidation and reduction phenomena, caused by the use of oak barrels, like the reduction of the volatility of certain compounds, such as esters, alcohol and aldehydes, due the wood contact and the lack of formation of others compounds which give pleasant aromas such as lactones, vanillin, among others (Conner et al., 1999; Escalona et al., 1999, 2002; Gagliole, 2013). The aroma of this wine can be improved by increasing maturation time in oak barrels after the stabilization period. It is important to highlight, this technique is being used in many wineries, but no scientific studies have been found on the subject.

It is important to emphasize 'Marselan' wines may have a more vegetal aroma due to its crossing between 'Grenache' and 'Cabernet Sauvignon'. This can be attributed to the green tones found in the wines, mainly for IV. In addition to the influence of the grape variety, cold regions also influence the vegetal aroma in the wines due to slower grape ripening (Miele and Rizzon, 2011). To decrease the perception of the vegetal aroma, it is necessary to use processes which promote the extraction of compounds and give more fruity tones such as ethyl esters and acetates.

Observations showed the winemaking process influenced the concentration of the compounds, causing changes in the sensory characteristics of wines. The different methods used did not allow the detection of different compounds between wines, only changes in their concentrations. This is expected since all other variables were controlled, including grape variety and crop, which are considered the major causes of change in the volatile composition of wines (Mihnea et al., 2014; De Castilhos et al., 2019; Ma et al., 2020; Piras et al., 2020). However, the concentration of volatile compounds and the physicochemical characteristics caused great differences between the wines, demonstrating the effect of the winemaking processes on the wine quality.

\section{CONCLUSIONS}

Chemometric analysis was useful for the study and showed a clear distinction between the winemaking processes. It was possible to verify the impact of different winemaking processes on the volatile composition and sensory characteristics of the wines. The wines from TV and CWUS presented compounds with fruity and overmaturation tones due to the temperature applied in TV wines. This caused the softening of berry peels and generated a higher probability of aromatic precursors to break. The ultrasound pretreatment increased the mass transfer rate. In order to obtain better results for IV, it is necessary for the wine to be in contact with the oak barrels for a longer period. This prolonged contact will help mask the strong vegetal aroma and increase the extraction of compounds responsible for the production of spicy aromatic notes. The TV and CWUS winemaking processes promote fruity, spicy, and overmaturation notes and can help to improve the vegetal aroma from the 'Marselan' cultivar. This study is important because the consumption of 'Marselan' wine is increasing, especially in new world countries. Winemaking processes directly affect the aromatic quality of wines due to different extraction rates of several compounds, contributing to various aromatic profiles. This study contributes to improving the quality of elaborated wines, allowing winemakers to choose new winemaking processes to enhance the aromatic compounds naturally present in the grapes.

\section{ACKNOWLEDGMENTS}

The authors would like to thank Villaggio Grando Winery for providing the grapes used in the study and all the wine experts who conducted the winemaking and sensory analysis protocols at Embrapa Grape and Wine - Bento Gonçalves. The authors also thank Georgia Lytra for scientific support and Dana Maria C. for English language editing and review.

\section{REFERENCES}

Baiano A., Scrocco C., Sepielli G., Nobile M.A., 2016. Wine Processing: A critical review of physical, chemical, and sensory implications of innovative vinification procedures. Crit. Rev. Food Sci. Nutr., 56, 2391-2407.

Bernardi G., Vendruscolo R.G., Ferrão T.S., Barin J.S., Cichoski A.J., Wagner R., 2014. Jelly palm (Butiaodorata) wine: Characterization of volatile compounds responsible for aroma. Food Anal. Methods, 7, 1982-1991.

Conner J.M., Paterson A. Piggott J.R., 1999. Release of distillate flavour compounds in Scotch malt whisky. J. Sci. Food Agr., 79, 1015-1020. 
De Castilhos M.B.M., Del Bianchi V.L., Gómez-Alonso S., GarcíaRomero E., Hermosín-Gutiérrez I., 2019. Sensory descriptive and comprehensive GC-MS as suitable tools to characterize the effects of alternative winemaking procedures on wine aroma. Part I: BRS Carmem and BRS Violeta. Food Chem., 272, 462-470.

Dominguez A., Agosin E., 2010. Gas chromatography coupled with mass spectrometry detection for the volatile profiling of Vitis vinifera cv. Carménère wines. J. Chil., 55, 385-391.

Escalona H., Birkmyre L., Piggott J.R., Paterson A., 2002. Effect of maturation in small oak casks on the volatility of red wine aroma compounds. Anal. Chim. Acta, 458, 45-54.

Escalona H., Piggott J.R., Conner J.M., Paterson A., 1999. Effect of ethanol strength on the volatility of higher alcohols and aldehydes. Ital. J. Food Sci., 11, 241-148.

Fariña L., Villar V., Ares G., Carrau F., Dellacassa E., Boido E., 2015.Volatile composition and aroma profile of Uruguayan Tannat wines. Food Res. Int., 69, 244-255.

Ferraretto P., Celotti E., 2016. Preliminary study of the effects of ultrasound on red wine polyphenols. CyTA-J. Food, 14, 1-7.

Gagliole, 2013. Vinificazione integrale. Available at: http://www.gagliole.com/wp-

content/uploads/2013/07/Integral_Vinification_en.pdf (accessed 21.08.2020).

Geffroy O., Lopez R., Serrano E., Dufourcq T., Gracia-Moreno E., Cacho J., Ferreira V., 2015. Changes in analytical and volatile compositions of red wines induced by pre-fermentation heat treatment of grapes. Food Chem., 187, 243-253.

Gómez E., Martínez A., Laencina J., 1995. Changes in volatile compounds during maturation of some grape varieties. J. Sci. Food Agr., 67, 229-233.

Guerra C.C., 2002. Maturação da uva e condução da vinificação para a elaboração de vinhos finos. In: Simpósio Mineiro de Viticultura e Enologia. Viticultura e Enologia: atualizando conceitos, 179-192.

Guth H., 1997. Quantitation and sensory studies of character impact odorants of different white wine varieties. J. Agric. Food Chem., 45, 3027-3032.

INRA, 2020. Available at: http://www7.inra.fr/internet/Directions/DIC/ACTUALITES/DOSSI ERS/qualite-aliments/vin-cepage-'Marselan'.htm (accessed 21.08.2020).

Jiao L., Ouyang S., 2019. The Chinese wine industry. In: The Palgrave Handbook of Wine Industry Economics. 225-246. Ugaglia A.A., Cardebat J.-M., Corsi A. (eds.). Palgrave Macmillan, Cham.

Lorrain B., Tempere S., Iturmendi N., Moine V., de Revel G., Teissedre P.L., 2013. Influence of phenolic compounds on the sensorial perception and volatility of red wine esters in model solution: An insight at the molecular level. Food Chem., 140, 7682

Lytra G., Tempere S., Le Floch A., de Revel G., Barbe J.C., 2013. Study of sensory interactions among red wine fruity esters in a model solution. J. Agr. Food Chem., 61, 8504-8513.

Lyu J., Ma Y., Xu Y., Nie Y., Tang K., 2019. Characterization of the key aroma compounds in 'Marselan' wine by gas chromatography-olfactometry, quantitative measurements, aroma recombination, and omission tests. Molecules, 24, 2978-2993.

Ma H., 2017. Cool climate wine production in China. Wine Vit. J., 32, 23-25.
Ma Z., Yang S., Mao J., Li W., Li W., Zuo C., Chu M., Zhao X., Zhou Q., Chen B., 2020. Effects of shading on the synthesis of volatile organic compounds in "Marselan" grape berries (Vitis vinifera L.). J. Plant Growth Regul. https://doi.org/10.1007/s00344-020-10123-2.

MAPA, 2018. Instrução normativa $\mathrm{n}^{\circ} 14$, de 08 de fevereiro de 2018. Complementação dos Padrões de Identidade e Qualidade do Vinho e Derivados da Uva e do Vinho. Available at: https://www.ibravin.org.br/admin/arquivos/informes/1522161859an.pdf (accessed 21.08.2020).

Mason T.J., 1998. Power ultrasound in food processing - the way forward. In: Ultrasound in food processing. 105-126. Povey M.J.W., Mason T.J. (eds.). Blackie Academic \& Professional, London.

Miele A., Rizzon L.A., 2011. Discrimination of Brazilian red varietal wines according to their sensory descriptors. Cienc. Agrotec., 35, 1172-1176.

Mihnea M., González-Sanjosé M.L., Ortega-Heras M., PérezMagariño S., 2014. A comparative study of the volatile content of Mencía wines obtained using different pre-fermentative maceration techniques. LWT - Food Sci. Technol., 64, 32-41.

Morgano M.A., Queiroz S.C.N., Ferreira M.M.C., 1999. Aplicação da análise exploratória na diferenciação de vegetais. Brazil. J. Food Technol., 2, 73-78.

OIV, 2019. Compendium of international methods of analysis of wines and musts. International Organisation of Vine and Wine, Paris.

Ostapenko V., Tkachenko O., Iukuridze E., 2017. Sensory and chemical attributes of dessert wines made by different freezing methods of 'Marselan' grapes. Ukr. Food J., 6, 278-290.

Peinado R.A., Moreno J., Bueno J.E., Moreno J.A., Maurício J.C., 2004. Comparative study of aromatic compounds in two young white wines subjected to pre-fermentative cryomaceration. Food Chem., 84, 585-590.

Perestrelo R., Fernandes A., Alburquerque F.F., Marques J.C., Camara J.S., 2006. Analytical characterization of the aroma of Tinta Negra Mole red wine: Identification of the main odorants compounds. Anal. Chim. Acta, 563, 154-164.

Pineau B., 2007. Contribution à l'étude de l'arôme fruité specifique des vins rouges de Vitis vinifera L. Cv. Merlot noir et Cabernet Sauvignon. 228 p. PhD Thesis, Université Victor Segalen Bordeaux 2.

Piras S., Brazão J., Ricardo-da-Silva J.M., Anjos O., Caldeira I., 2020. Volatile and sensory characterization of white wines from three minority Portuguese grapevine varieties. Ciência Téc. Vitiv., 35, 49-62.

Plaza E.G., Jurado R., Iniesta J.A., Bautista-Ortín A.B., 2019. High power ultrasounds: A powerful, non-thermal and green technique for improving the phenolic. Bioweb of Conferences 41st World Congress of Vine and Wine, 12, 02001.

Robinson J., Harding J., Vouillamoz J., 2013. Wine Grapes: a complete guide to 1368 vine varieties, including their origins and flavours. 1248 p. Penguin Random House, London.

Shinohara T., 1985. Gas chromatographic analysis of volatile fatty acids in wines. Agr. Biol. Chem., 49, 2211-2212.

Toma M., Vinatoru M., Panywnyk L., Mason T.J., 2001. Investigation of the effects of ultrasound on vegetal tissues during solvent extraction. Ultrason. Sonochem., 8, 137-142. 
Vilanova M., Genisheva Z., Graña M., Oliveira J.M., 2013.Determination of odorants in varietal wines from international grape cultivars (Vitis vinifera) grown in NW Spain. S. Afr. J. Enol. Vitic., 34, 212-222.

Villamor R.R., Ross C.F., 2013. Wine matrix compounds affect perception of wine aromas. Annu. Rev. Food Sci. T., 4, 1-20.
Wang J., Huo S., Zhang Y., Liu Y., Fan W., 2016. Effect of different pre-fermentation treatments on polyphenols, color, and volatile compounds of three wine varieties. Food Sci. Biotechnol., 25, 735-74.

Zea L., Moyano L., Moreno J., Cortes B., Medina M., 2001. Discrimination of the aroma fraction of Sherry wines obtained by oxidative and biological ageing. Food Chem., 75, 79-8. 